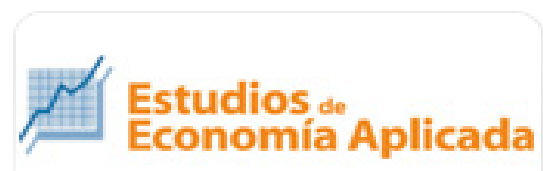
Ectudios de Aplicada

\section{Estudios de Economía Aplicada}

ISSN: 1133-3197

secretaria.tecnica@revista-eea.net

Asociación Internacional de Economía

Aplicada

España

CAÑIBANO, M. LEANDRO; SANCHEZ, PALOMA

Intellectual Capital Management and Reporting in Universities and Research Institutions

Estudios de Economía Aplicada, vol. 26, núm. 2, agosto, 2008, pp. 7-25

Asociación Internacional de Economía Aplicada

Valladolid, España

Available in: http://www.redalyc.org/articulo.oa?id=30113187001

How to cite

Complete issue

More information about this article

Journal's homepage in redalyc.org

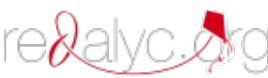

Scientific Information System Network of Scientific Journals from Latin America, the Caribbean, Spain and Portugal Non-profit academic project, developed under the open access initiative 


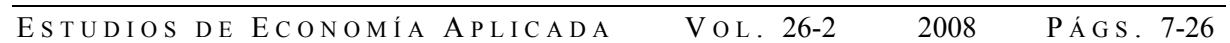

\title{
Intellectual Capital Management and Reporting in Universities and Research Institutions ${ }^{1}$
}

\author{
LEANDRO CAÑIBANO M. \\ Prof. of Accounting and Finance. Autonomous \\ e-mail: leandro.canibano@uam.es \\ PALOMA SANCHEZ \\ Prof. of Applied Economics. Autonomous \\ UNIVERSITY OF MADRID \\ e-mail: mpaloma.sanchez@uam.es
}

\section{ABSTRACT}

The paper intends to show how the IC principles, developed mainly for companies over the last two decades, can be applied as well to Universities and Research Institutions. Firstly, it explores recent theoretical backgrounds which affect Universities, such as the "Mode 2" of Knowledge production and the Triple Helix Model. Secondly it analyses how similar objectives and procedures are when managing intangibles in both companies and Universities. Then it examines whether the structure of IC reporting in companies may be useful for Universities, providing some examples for Europe, and how the harmonization and external control principles are relevant for public institutions. The main conclusion is that IC principles can broadly apply to Universities and that reporting on their IC would be beneficial for them and the society as a whole, which provides the rationale for public intervention.

Keywords: Intangibles; Intellectual Capital; Universities; Research Institutions.

\section{Gestión e información del capital intelectual de las universidades e instituciones de investigación}

\section{RESUMEN}

Mediante este artículo se pretende mostrar cómo los principios en los que se basa el 'Capital Intelectual', desarrollados principalmente durante las dos últimas décadas en el ámbito empresarial, pueden ser también aplicados a las Universidades e Instituciones de investigación. Para ello se exponen, en primer lugar, los fundamentos teóricos más recientes que afectan a las Universidades, tales como el 'Modo 2' de producción de conocimiento y el 'Modelo de triple hélice'. En segundo término, se analiza la existencia de objetivos y procedimientos similares para gestionar los intangibles, tanto en las empresas como en las Universidades. Seguidamente se examina si la estructura del Informe de Capital Intelectual utilizado por las empresas podría servir para el de las Universidades, proporcionando algunos ejemplos relativos a Europa, y poniéndose igualmente de manifiesto que la armonización y los principios de control externo son también relevantes para las instituciones públicas. La principal conclusión a la que se llega es que la aplicación de los principios que informan el Capital Intelectual puede extenderse al ámbito de las Universidades y que la emisión por parte de éstas de un Informe de Capital Intelectual podría ser beneficioso para ellas y para el conjunto de la sociedad, proporcionando así una exposición razonada de la intervención pública.

Palabras clave: Intangibles; capital intelectual; universidades; instituciones de investigación.

Clasificación JEL: I23, I28, M14.

Artículo disponible en versión electrónica en la página www.revista-eea.net, ref. อ-26201.

\footnotetext{
${ }^{1}$ An earlier version of this paper was presented at the 2005 PMA IC SYMPOSIUM: Management and Measurement of Intangible Assets and Intellectual Capital: Multidisciplinary Insights. New York University, 15-16 December 2005. We appreciate the comments and suggestions received during that meeting. This paper has been produced within the activities of the PRIME (Policies for Research and Innovation in the move towards the European Research Area) Network of Excellence, funded by the European Commission.
} 


\section{INTRODUCTION}

Over the second half of the $20^{\text {th }}$ century the main economic theories have recognised, to a greater or lesser degree, the existence of intangible elements that explain part of the economic growth (Solow, 1957; Deninson, 1962; Arrow, 1962; Shultz, 1969; Kendrick, 1974; Becker, 1975; Freeman, 1982; Nonaka \& Takeuchi, 1995; Gorey \& Dobat, 1996; OECD, 1996; European Commission, 2000). This interest has continued growing during the first decade of the current century.

Despite the apparent novelty of the issue, the concept of Intellectual Capital is not at all new. Nassan William Senior, 150 years ago, argued that the Intellectual Capital of Great Britain far exceeded all the material capital not only in importance, but in productivity (Senior, 1836). However, since then, the IC has been mostly ignored in the decision-making process for investments in $R \& D$, although it is considered "the hidden driver of the Knowledge-based economy" (European Union, 2005a, p. 4).

The last decade has witnessed an incredible increase in the interest in Intellectual Capital and how accurate measuring, managing and reporting may help companies to better achieve their goals. Academics and professionals alike are devoting attention to best practices and trying to develop theories to explain how intangibles are affected by actions and are transmitted to performance. The amount of literature on intangibles and intellectual capital has multiplied by five over the last decade (Sánchez and Basilio, 2008).

The interest in the Intellectual Capital issue is now transferring to public institutions, such as Universities and Research Centres. Initiatives to encourage these organizations to manage and report on their intangibles are growing and the differing experiences are being studied to see what the advantages and shortcomings are of the exercise. Attention to this type of institution in the Intellectual Capital or Knowledge Management literature was an exception ten years ago but is now a much more common issue (ibid.).

This paper intends to show, first, whether and why it makes sense to recommend Universities to manage and report their IC. Section 1 attempts to answer this. Section 2 is devoted to how the objectives and concerns for companies may also be applied to Universities. Section 3 presents some recent experiences and results of a project called the Observatory of European Universities to suggest that the IC reporting structure followed by companies may be useful for Universities as well. Section 4 suggests that harmonization and auditing issues are still unsolved problems and, finally, Section 5 provides some conclusions.

\section{IC REPORTING IN UNIVERSITIES. DOES IT MAKE SENSE?}

\subsection{Business Practices in Universities}

Universities and Research Organisations are producing knowledge; their funds are mainly invested in research, innovation and human resources. Therefore, both their 
most valuable assets are most often intangible by nature, as are their outputs. Unfortunately, however, a very small proportion is considering identifying, measuring and valuing intangibles as part of an overall knowledge management programme. Historically this has been caused (among other factors) by organisational characteristics - most are public organisations, seldom obligated to produce annual financial accounts or alike - and by organisational culture, where little emphasis is placed on developing management systems and strategic orientations. However this scenario is changing, because of the increasingly important role of private universities and for-profit research organisations, and also because of clear-sighted leaders who recognise the value added benefits of embedding such activities in their systems (Cañibano and Sánchez, 2004; p. 100).

There is currently a movement in Europe towards increasing the autonomy of universities and research organisations, often based on principles of new public management with its inherent logic of performance orientation, measurement and resource allocation. The transformation of the science and innovation system towards increased co-operation between different organisations, new modes of knowledge production (e.g. interdisciplinary research), new political targets (Bologna process and European Research Area) and various forms of funding and financing across Europe, are driving factors facing both universities and research organisations. Thus, the competition between universities and research organisations will increase in the future, and they will have to position themselves strategically, raise new financial resources and find new ways of accounting for their investments and expenditures. In fact the different stakeholders of these diverse organisations, not only funding agencies but also industry and society, are already demanding greater transparency for the efficient use both of funds and of the generated outputs.

Quality is another goal, traditionally pursued by companies, which is increasingly sought after in Universities. Accordingly, the European Network of European Higher Education (ENQA) is working "actively in the process towards ensuring a credible European quality assurance environment" (European Network for Quality Assurance in Higher Education, 2003; p. 3). The appearance of quality as a relevant issue in university discourse shows an initial, but important, awareness with respect to managing and publishing information about intangibles (Sánchez and Elena, 2006).

In response to these challenges, universities and research organisations are already implementing new management and reporting systems, which must incorporate intangibles. The organisations that gain first mover advantage by developing and embedding procedures first will clearly enjoy a strategic advantage over their peers (Leitner, 2002). As we will argue later on, we share with other authors (Mouritsen et al., 2005; Leitner et al., 2005; Alqvist and Skoog, 2007) the opinion that the Intellectual Capital framework is adequate for helping Universities to better manage and diffuse their knowledge creation processes to their stakeholders and society at large (Sánchez, Elena and Castrillo, 2008). 


\section{2. "Mode 2" of Knowledge Production and the Triple Helix Model}

The current role of universities in the knowledge-based economy may be analysed from the perspective of new theories in evolutionary economics, such as "Mode 2" of Knowledge Production and the Triple Helix Model.

R\&D policies adopted during the Cold War period were based on the linear model of innovation and favoured specific disciplinary research agendas. This is what we could call "Mode 1" of knowledge production. The end of transatlantic tensions leading to the rise of new techno-economic paradigms and the need to speed up business transactions and force institutional adaptation provided the necessary impulse for a shift in the way private and public organisations regarded their research efforts. In this scenario, knowledge creation is more comprehensive and open to approaches responding to socioeconomic, institutional and corporate needs (Sánchez and Elena, 2005 and 2006). "Mode 2" is defined by dynamic trans-disciplinary links between academia and industry, according to "solution-focused" and "design-oriented" models characterised by a "constant flow back and forth between the fundamental and the applied, between the theoretical and the practical" (Gibbons et al., 1994; p. 19). Now "knowledge production and dissemination - teaching and research - are no longer self contained activities, carried out in relative isolation. They now involve interaction with a variety of other knowledge producers" (Gibbons, 1998; p. 1). This framework is now widely accepted and has become crucial to understand not only the role of today's universities but also their links with other actors in the current economy (Mowery and Sampat, 2004).

The European Commission states very clearly (2003; p.13) that "universities have a duty to their stakeholders (students, public authorities funding universities, labour market, society as a whole) to maximise the social return of the investment". The two traditional "duties" of Universities (teaching and research) are now reinforced with a third one: To serve society as a whole and be in step with the surrounding area.

This directly links with the Triple Helix Model proposed by Etzkowitz and Leydessdorff where University-Industry-Government relations are analysed "in terms of three interlocking dynamics: institutional transformations, evolutionary mechanisms and the new position of the university" (Etzkowitz \& Leydessdorff, 2001; p.6). The National Systems of Innovation framework (Lundvall, 1992 and Nelson, 1993) considers firms the leading players in the innovation processes. The difference is that the Triple Helix postulates consider the three spheres as having equal importance in the innovation network (Sánchez and Elena, 2006).

There was an academic revolution in the late nineteenth century in which research was incorporated into the university's mission, making it compatible with teaching activities. Although there is a tension between these two activities, they co-exist "because it has been found to be both more productive and cost effective to combine the two functions" (Etzkowitz \& Leydessdorff, 2001; p. 11). This process of change has led to a "re-evaluation of the mission and the role of the university in society"; the Triple Helix thesis assumes "that the university can play an 
enhanced role in innovation in increasingly knowledge-based societies" (Etzkowitz \& Leydessdorff, 2001; pp. 1-2).

Now it is widely accepted that Universities have a "third mission" which refers to activities addressed to satisfy social needs and private or public economic objectives (Molas-Gallart, 2005). However, as we have stated elsewhere (Sánchez, Elena and Castrillo, 2008) the notion of "third mission" is still ambiguous and differs greatly from one university to another, depending on the type of activities developed, the territorial embedding and the institutional framework of the country (Laredo, 2007).

\subsection{Some Policy Recommendations}

Universities are unique in the process of production, transmission and dissemination of knowledge. For that reason, the European Commission considers that "investing more and better in the modernisation and quality of universities is a direct investment in the future of Europe and Europeans" (European Commission, 2005b; p. 2), and is pushing the reporting of Intellectual Capital by Universities through a recent activity. In December 2004 the D.G. Research set up a High-Level Expert Group to recommend a set of measures to stimulate small and medium sized companies to report on their intangibles. By doing so, the Expert Group has also taken into consideration the relationship between SMEs and Universities and the need of these latter institutions to report on their Intellectual Capital. The main assumption which supports the recommendations for reporting is that Intellectual Capital is the hidden driver of the knowledge-based economy and that diffusing information on IC may stimulate and make the organizations' $R \& D$ efforts more visible. The document produced by the Group (European Commission, 2006a) titled (Reporting Intellectual Capital to augment research, development and innovation in SMEs) includes among the policy recommendations the need for both the Commission and the member states to promote the spread of IC framework in universities and research and technology organizations.

RICARDIS assumes the definition for IC provided by the MERITUM project (MERITUM, 2002) which considers IC as the combination of an organization's Human, Organizational and Relational resources and activities. IC can be both the product of $R \& D$ activities and the enabler for creating greater value from $R \& D$. This combination of intangible resources and activities allows an organisation to transform a bundle of material, financial and human resources in a system capable of creating stakeholder value.

In relation to Universities the report argues that they have been confronted with new kinds of challenges in recent years, having to compete increasingly for research funds and to cope with new research modes: Competition on commercial markets, market orientation and competitive based funding are becoming more and more common for this sector, which, in turn, demands a more progressive way of communicating with the stakeholders and of measuring their performance. The 
report also considers that higher education institutions are going through a period of important transformations ('Bologna Process' and the proposed 'European Higher Education Area'), and in this new context, IC Reporting could improve both the transparency in governance and in their resource management. It also refers to the previously mentioned "third mission" of Universities which "includes the relationships between the university and its non-academic partners: industry, public authorities and the general public. Some of these relationships have clear economic consequences and are referred to as "knowledge transfer". Some others however are of a more social nature and show their territorial embedding. Thus, university researchers may be involved in social activities that increase the public understanding of science, which may have a strong long term impact in research efforts, and they may also be involved in policy formulation".

As a consequence the RICARDIS report messages are very clear. It is suggested that:

1. Universities and similar institutions be assisted to see the advantages, both for their internal management and for their relations with society, of managing and reporting IC.

2. Under-graduate and postgraduate education and training in the identification, management and communication of intangible assets be provided to students, and.

3. Funding agencies establish IC reporting requirements, but only in an environment of increased support and funding and not as a tool for cutting back or budget restriction.

Other public entities are also encouraging Universities to report on their intangible resources and activities to society as a whole, as a response to the greater autonomy they are given. This is for example the case of the Portuguese and Spanish Governments, who issued new Laws for Education in 2007 (Ministério da Ciência, Tecnologia e Ensino Superior, 2007; Jefatura del Estado, 2007) which considered University accountability an fitting counterpart to such autonomy. This is also the case of the European Universities Association (2005 and 2007) which recommends Governments to increase their funding to Universities and provide them with more autonomy, while they, in turn, correspond with increasing support of societal needs and incrementing diffusion of information on their activities.

All these new demands on Universities call for new management and reporting mechanisms. If they are to behave more like business companies, they should be provided with instruments which allow them to fulfil such new requirements. 


\section{SOME OF THE MAIN CONCERNS IN COMPANIES. ARE THEY THE SAME FOR UNIVERSITIES?}

Some of the main concerns for companies are addressed in this point. They refer to the effects of IC management in their value creation process, the societal demands for more responsibility, their relationships with external partners and allies and the effect of IC disclosure on capital markets. The objective is to highlight how these concerns may be similar for Universities and Research Organizations.

\subsection{The Value Creation Process}

It is clear that IC management and reporting make sense for companies if the exercise creates value for the stakeholders, and this happens if profit increase or market value increases or both. It is obvious that public Universities do not make profits and there is no market value for their inexistent shares but a good deal of the intangibles we are considering are either knowledge or directly linked with knowledge production and diffusion, and measuring knowledge is difficult in all organizations.

Although there is a general consensus about the necessity for new measurement techniques, there are important obstacles when measuring knowledge for many different reasons: an important part of knowledge is implicit; the different elements of knowledge are heterogeneous; knowledge is not observable, etc. (Foray, 2004). Foray also highlights how the terms and magnitude of the relation between the creation of knowledge, its diffusion, and economic growth are not known.

Extracting value from intellectual capital is more complicated and risky than extracting value from tangible capital and although it is clear that firms would not invest in intangibles (such as R\&D) unless they perceived that it pays off, quantifying the value of intangibles and the returns they generate is not easy (Augier and Teece, 2005; pp. 18-21). Even though it is generally accepted that intangibles create added value, this cause-effect chain has not yet been quantified (Lev, 2001).

However to measure the intangibles is a very important matter, for several reasons. First, it is extremely hard to manage assets that one cannot describe or measure or to determine success or failure in asset management activities. Also, if intangibles are not measure correctly, an organization might appear to be doing poorly when in fact it is simply investing in intangibles (Augier and Teece, 2005; pp. 20-21).

Apart from this it is difficult for intangibles to create value on their own. To do so they have to interact with other assets (tangible or intangible) (Marr and Roos, 2005; p. 36). They rightly quote Baruch Lev (2001; p. 7) noting that "intangibles are frequently embedded in physical assets ... and in labour..., leading to considerable interactions between tangible and intangible assets in the creation of value... When such interactions are intense, the valuation of intangibles on a standalone basis becomes impossible”.

In conclusion, it is difficult to relate IC to performance in companies (Cañibano and Sánchez, 2004; pp. 90-91) so it will be difficult to do it in Universities. All the 
above arguments related to companies could be repeated for Universities; the main differences would be the indicators to measure performance. Only some indicators would be the same, such as patents; most of them, however, would differ. Margins, market share and market value would not be appropriate but captured financial funds for research, research contracts with industry, attractiveness for the best teachers and students, etc. could very well be indicators for performance in Universities.

\subsection{Corporate Social Responsibility}

Both companies and Universities have to provide responses to new social demands. Although, in recent years, there has been a growing concern that business reporting is inadequate and many ideas put forward on possible reforms, there is no agreement on what should be done (Institute of Chartered Accountants in England and Wales, 2005). The Corporate Social Responsibility (CSR) is defined by AECA (2004) as a new company dimension concerned with the firm sustainability and its impact on the economic, social and environmental arena. It is a commitment made by a group of people to interact with society and to contribute to its amelioration.

Different national and international organizations have issued guidelines, either compulsory or voluntary, for social and environmental reporting. This is the case in France, Germany, UK, Denmark and Sweden in Europe, and Canada and Argentina in America. A well-known international guideline is the Global Reporting Initiative (GRI), whose general objective is to provide information about CSR; the $3^{\text {rd }}$ version of that guideline G3 (2006) is applied worldwide, with Spanish companies taking the lead in its implementation. The European Commission issued a recommendation on measurement and reporting in financial statements of environmental expenses, assets, liabilities and contingencies, which was adopted on a compulsory basis by several EU members, Spain included (ICAC 2002). More recently the European Commission issued a communication (2006b) to the European Parliament, the Council and the Economic and Social Committee on the implementation of CSR with the intention of making Europe a pole of excellence in CSR. The United Nations has launched its 'Global Compact' programme in order to voluntarily align companies and other entities, Universities among them, with a set of principles on human rights, labour, the environment and corruption (Williams 2004); Spain is well ahead in relation to the number of companies and other entities who have signed that commitment.

Another hot topic in the business environment nowadays is Corporate Governance which is related to the way in which companies are organized, managed and controlled, while taking into consideration different stakeholders' interests: shareholders, board, managers, employees, and other third parties involved in the workings of the company. Corporate Social Responsibility and Corporate Governance are interrelated, with an on-going academic debate about which of the two con- 
cepts should prevail. For some people, for example, Thomsen (2006) CSR is a tool to implement Corporate Governance, while for others CSR is the umbrella, underneath which, according to the organization's culture and values, Corporate Governance is implemented (AECA, 2007). This latter approach is now receiving attention in internationally renowned business schools, such as the Stanford Graduate Business School and ESADE in Spain (Expansión, 2008).

Social responsibility is in ever greater demand, not only from large and multinational companies, but other organizations such as Governmental agencies, Universities and research centres (Congreso de los Diputados, 2007). For that reason, the previous comments on CSR reporting can be applied not only to companies but to Universities too. As a part of the Third Mission activities, previously mentioned, Universities have to prove to be Socially Responsible, and show that they are responding to societal demands.

\subsection{Alliances and Networks. Effects on Markets}

The alliances and networks, a part of the Relational Capital, is also a common concern for both types of institutions. Just as companies cannot innovate in isolation, universities increasingly rely on their inter-relationships.

One important problem related to most of the intangibles included in the Relational Capital category, alliances and networks in particular, is to identify quantitative indicators for them and to link their existence to performance. Again, this difficulty is common for both companies and Universities.

Companies compete on capital markets and the advantages of disclosing information about their IC have been duly documented. Different studies show how disclosure reduces asymmetries, increases transparency and thus diminishes the cost of capital (Cañibano and Sánchez, 2004; pp. 93-95).

The RICARDIS report previously mentioned sees two types of effects in IC reporting by companies. A) It contributes to the internal management and B) It complements the external information provided, thus having an effect on capital markets.

The same two effects could be mentioned in relation to Universities. A) It may have several internal effects, since it may help to identify where the main assets are and to improve the decision making process (allocation of new resources, for example). B) It has also external effects. Universities and Research Institutions do not compete on capital markets, but information asymmetries are also of relevance for them since they have to compete for research grants and funds, for students and teachers.

Bossi et al. (2005) have produced an Intellectual Capital Model for public institutions. The model incorporates five variables that influence the public sector: Human Resources, Internal Organisation, External Relations, Quality and Transparency. A main contribution of this model, in our opinion, is the inclusion of the concept "Intellectual Liabilities". The author defines it as "the lack of Intellectual 
Capital presented by an institution" (Bossi, 2003; p. 212). In this way, it is argued that most of the models and analysis undertaken by and for private companies focus on the added value of an adequate management of intangibles, but do not make explicit the effects produced by a lack of intangibles management. Following this line, and taking into account that transparency on the use of public funds should be a priority for public organisations, Intellectual Liability becomes essential to effective management of public intellectual capital. (Sanchez and Elena, 2006).

The importance of external relations for companies has been stressed by the OECD in the latest version of the Oslo Manual, devoted to measuring innovation (OECD, 2005). A whole new chapter highlights the importance of relations and networks and the positive effect they might have on innovative capacity. The relationship with Universities in this regard is specifically mentioned in the Manual and, in our opinion, the difficulties private institutions may have in accounting and valuating the connections, are very similar to those Universities are facing. It is also equally important for both to encourage and take advantage of them in the knowledge creation process.

\section{THE STRUCTURE OF IC REPORTING. IS IT USEFUL FOR UNIVERSITIES?}

\subsection{Some International Experiences}

The RICARDIS document is clearly recommending the use of the three categories (Human, Structural and Relational Capital) when reporting IC by Universities and Research Organizations. Its advice is based on some international experiences. The main one is that of the Austrian Research Centres (ARC), the biggest Research and Technology organization in Austria, and has an important function as a link between basic research in universities and applied research carried out by companies. They published their first IC report for year 1999.

The experience of ARC has been so convincing that IC reporting has become mandatory for all Austrian universities since 2006, the year in which an Order came into force stemming from a university law issued in 2002. The Austrian Ministry of Education adopted the idea of IC reporting to enhance transparency, foster the management of intangibles, and set initiatives for performance orientation (Sánchez and Elena, 2006). The model suggested for reporting is based on the usual breakdown of Human, Structural and Relational Capital. The introduction of IC Reports shows how the Austrian Government considers "the efficient use of IC [as] essential for a university's performance" (Leitner et al., 2005). Although the analysis of the first year results are not yet available, some trial exercises were set up by two departments of Vienna University (Altenburger and SchaffhauserLinzatti, 2006). The expected outcomes of the IC Report requirement and some policy recommendations for avoiding unintended negative consequences are detailed in Sánchez, Elena and Castrillo (2008). 
Other experiences, following the same structure, are those of DLR, a German research organization (Leitner, 2005 and Leitner and Warden, 2003); an Innovation and Knowledge Management Institute in Valencia (INGENIO, 2002); an initiative led by the members of the European Association of Research Managers and Administrators (EARMA) in collaboration with the European Center for the Strategic Management of Universities (ESMU) called Intellectual Capital in Higher Education and Research Organisations (HEROs) (Warden, 2003); an Intellectual Capital Indicators Programme - PCI Project (2000-2003) - applied to universities and research centers in the Madrid area (Comunidad de Madrid, 2002); the University of the Basque Country (UPV) has developed a knowledge management case-study project in a key and strategic cross-organisational process (Araujo, 2000); the Norwegian Competence Report (Norwegian Ministry of Education and Research, 2004); the Learning Conditions Monitor (Nyen et.al., 2004), and the Intellectual Capital Report (CMM Center for Molecular Medicine, 2005).

These IC Reports, some of them quoted in the RICARDIS report, like those for private industrial firms, reveal information about organisational goals, illustrate the development of IC based on narrations and provide indicators for the different forms of IC and, especially, about research results.

As mentioned before, although Universities do not compete on capital markets, information asymmetries are also of relevance for them since they have to compete for research grants and funds. Students, teachers, financiers, funding agencies, etc. have to take their decisions on the best available information, which should preferably deal with the organisational capacity and research potential of an organisation. These institutions may reduce the information asymmetries in order to facilitate technology transfer with industry and to communicate their competencies and products. Quoting the RICARDIS report "research is not self-explanatory; its benefits must be interpreted and communicated in a comprehensible way".

\subsection{The Observatory of European Universities (OEU)}

The higher education system in Europe is organised following national and regionnal structures. Due to this, the European university panorama is mainly characterised by a "high degree of heterogeneity which is reflected in organisation, governance and operating conditions, including the status and conditions of employment and recruitment of teaching staff and researchers" (European Commission, 2003; p. 5).

In order to understand the European university system, to contribute actively towards excellence, and to improve university management processes in this changing context, an ambitious initiative was taken by the Observatory of European Universities. Their aim was to measure what counts today in Universities. It has been developed by the PRIME (Policies for Research and Innovation in the move towards the European Research Area) Network of Excellence, funded by the European Commission ${ }^{2}$.

\footnotetext{
${ }^{2}$ PRIME is composed by more than 40 European Universities and Research Institutions (the Autonomous University of Madrid among them), and more than 200 senior researchers. The two authors of this paper are members of the Network. www.prime-noe.org.
} 
The Observatory, created in June 2004, set out to improve understanding of the importance of managing intangibles (although this word is not used) in universities in order to improve their level of quality and competitiveness. Its overall objective was to provide them with the necessary tools and instruments for the governance of research activities. Fifteen universities and research institutes from eight different European countries worked together to develop a common framework of analysis and to build a battery of indicators to measure and compare the intangible elements related to research activities. Being aware of the complexity, the Observatory decided to start with research activities, even though the general aim is to extend the Project to teaching activities in the future.

The main outcome of the project has been a Methodological Guide (OEU, 2006) to help Universities in the management and diffusion process of their intangible resources and activities. The last Chapter of the Guide (Sánchez, Castrillo and Elena, 2006) is called "The Intellectual Capital Report for Universities" and develops a standard model for disclosure using IC language and methodology. It gives guidance in producing a "vision of the institution" and presenting the main "intangible resources and activities" the University counts on. Finally it suggests a "list of indicators" that, according to the experience of the institutions participating in the OEU exercise, can be built on, are useful for management purposes and likely to provide interesting information to society at large.

\section{HARMONIZATION AND EXTERNAL CONTROL. ARE THEY POSSIBLE?}

Harmonization and external control of IC reports are still areas where companies have not got very far either. Again, the similarity between the two groups (companies and Universities) appears.

The final report of the MERITUM project (downloadable at http://www.uam.es/meritum) highlighted a conflict of interest with respect to harmonization. On the one hand, some degree of harmonization both in the measurement processes and in the indicators provided is necessary, if we want to make comparisons between institutions, and across time within the same institution. On the other hand, the IC management and measurement process has to reflect the uniqueness of the institution, which calls for specific processes and indicators. Moreover, a particular institution (companies and Universities alike) may change from one year to the next as a consequence of its organizational innovation. There has to be room for innovation in the IC process.

Some of the MERITUM members stressed that a balance is needed between two types of indicators: a) "core indicators" which should be shared throughout the sector, useful for a medium term period and $b$ ) context driven indicators which should reflect the company's uniqueness. (Canibano and Sánchez, 2004; p. 102)

RICARDIS, on a similar line, is suggesting having 3 levels: A general one, made up of a basic set of indicators, a sector level, with sector specific indicators and an enterprise level, with company specific indicators. It is suggested that har- 
monization and standardization should affect the first level and that ad-hoc bodies should suggest standards for the specific sectors.

The report is also recommending the production of a taxonomy of intangibles so as to avoid the proliferation of words without a precise anchorage. Moreover, in the very same way as R\&D and innovation concepts of Frascati and Oslo Manuals on research and innovation are nurturing IC reports, IC concepts should be taken into consideration in the $\mathrm{R} \& \mathrm{D}$ and innovation questionnaires companies are used to receiving and filling in. All these tasks should be performed by a Task Force the report is recommending to create. The Task Force should be composed of the organisations that represent different stakeholders as well as the users of IC reports (employers, banks, accounting firms, managers, stock exchange agencies, trade unions, etc.).

The auditing issue is also an important and difficult one. The external verification of IC statements in companies is still in its infancy. Some have argued that methods similar to those used to certify Quality could be applied, which in fact means analyzing the processes followed. But there are already examples which show that a window of opportunity for external verification exists. In Spain, over the years 2004-2006, 30 quoted companies included in the IBEX 35 index, issued Corporate Social Responsibility reports, their verification being made in different ways, but mainly by External Auditors and the Auditing Committee. Usually the 'Auditor's opinion' certifies that the report has been produced following the criteria of the GRI. Auditors have even verified the calculation of a sample of indicators, which is to say that they have not limited themselves to the verification of the process, but given an opinion on the indicators provided. The CSR Observatory's Report $2006^{3}$ (2007) in Spain mentions the verification of reports for Santander and Gas Natural as examples of 'Auditor's opinion', and that of NH as an example of Auditing Committee verification.

It is not realistic to expect similar things for the University in the short run. However, it is true that Universities are used to going through external valuations for some of their processes. For example, teachers, research proposals, research results are subject to peer reviews. So, it is not unreasonable to envisage having an overall external analysis in relation to future IC reporting. The Austrian Universities Act issued in 2002, previously mentioned, establishing the obligation of Austrian Universities to provide IC reports in 2006, devotes a whole point to Evaluation and Quality assurance, indicating when external evaluation should take place and "who" may ask for it. The definition of "how" it should take place is being left for a future norm.

Both issues, harmonization and auditing are directly linked with benchmarking exercises. Benchmarking is an increasingly used practice. However, we must have in mind that to draw conclusions from it which might be used in policy recommendations is dangerous if there are no harmonized and standardization procedures and some sort of external control in place.

\footnotetext{
${ }^{3}$ Observatorio de RSC 2006.
} 


\section{SUMMARY REMARKS}

Since the second half of the $20^{\text {th }}$ century the main economic theories have recognised, to a greater or lesser degree, the existence of intangible elements that explain part of the economic growth. The last decade has witnessed an incredible increase in the interest in intangibles and Intellectual Capital and how their adequate measurement, management and reporting may help companies to better reach their goals. This interest is now moving to public institutions, such as Universities and Research Centres. Initiatives to encourage these organizations to manage and report on their intangibles are multiplying and the different resulting experiences are being studied to see the advantages and shortcomings of the exercise. This paper argues why it is reasonable to recommend Universities to manage and report their IC.

Universities and Research Organisations are producing knowledge; however, only a very small proportion is considering identifying, measuring and valuing intangibles as part of an overall knowledge management programme. Nevertheless, the situation is likely to change, because the increasing autonomy and competition among universities and research organisations will oblige them to position themselves strategically, raise new financial resources and find new ways of accounting for their investments and expenditures. In response to these challenges, universities and research organisations are already implementing new management and reporting systems, which must incorporate intangibles.

The current role of universities in the knowledge-based economy is analysed from the perspective of new theories in evolutionary economics, such as "Mode 2" of Knowledge Production and the Triple Helix Model. According to these, Universities now work much more closely with society (have a "third mission") and play a much more important role in the National System of Innovation framework.

The European Commission is pushing the reporting of Intellectual Capital by Universities. A High-Level Expert Group set up by the Commission is recommending Universities to use IC reporting both for their internal management and for diffusing their activities. It also recommends fostering under-graduate and postgraduate education and training in the identification, management and communication of intangible assets ${ }^{4}$.

It is extremely important to measure intangibles, since it is very hard to manage assets that cannot be described or measured. As many difficulties arise in relating IC to performance in companies as Universities but the indicators measuring it would differ in the two cases. Patents could be applied to both; but market share and market value would be inappropriate to Universities, while captured financial

\footnotetext{
${ }^{4}$ The Autonomous University of Madrid, together with the Complutense and the Polytechnique Universities of Madrid is running a PhD Programme (Quality Award 2006 from the Ministry of Education and Science) in Economics and Management of Innovation for 10 years. This Programme has been transformed into a Masters $+\mathrm{PhD}$ Programme from 2007-2008, following the new rules to adapt to the Bologna framework.
} 
funds for research, research contracts with industry, attractiveness for the best teachers and students, etc. could very well be used as indicators for their performance.

Both companies and Universities have to provide responses to new social demands. There has been growing concern in recent years that business reporting is inadequate. There are many ideas as to how it should be reformed, but there is no agreement on what should be done. Today Universities have to prove to be socially responsible, and show that they are responding to societal demands.

The alliances and networks, a part of the Relational Capital is also a common concern for both types of institutions. Just as companies cannot innovate in isolation, universities rely increasingly on inter-relationships. The effects of IC reporting in companies, both internal and external, can also be applied to Universities.

The several recent experiences at European level show that the three usual categories of Intellectual Capital (Human, Structural and Relational Capital) when reporting IC by Universities and Research Organizations are also useful for Universities. The Observatory of European Universities is an interesting example of how the concepts can be translated into practical suggestions.

Harmonization and external control of IC reports are still areas where companies have made little headway. Again, the similarity between the two groups (companies and Universities) appears. Some degree of harmonization both in the measurement processes and in the indicators provided is necessary, a balance is needed between two types of indicators: a) "core indicators" which should be shared across the same type of institutions, useful for a medium term period and b) context driven indicators which should reflect the institution's uniqueness. The external verification of IC statements is still in its infancy in companies. Universities or Research Centres, on the contrary, are used to external valuations for some of their processes. It may not take long for either institution to adapt to auditing its intangibles. Both issues, harmonization and auditing, are directly linked to benchmarking exercises, which is a practice increasingly used.

\section{REFERENCES}

AECA (2004): Marco Conceptual de la Responsabilidad Social Corporativa, Documentos AECA, Madrid.

AECA (2007): Gobierno y Responsabilidad Social de la Empresa, Documentos AECA, Madrid.

ALMQVIST, R. and SKOOG M. (2007): "Colliding discourses? New Public Management from an Intellectual Capital Perspective", In C. Chaminade and B. Catasus (Eds.), Intellectual Capital Revisited: Paradoxes in the knowledge-intensive organization, Edward Elgar, UK. Forthcoming, Cheltenham.

ALTENBURGER, O. y SCHAFFHAUSER-LINZATTI, M. (2006): "The Order on the Intellectual Capital Statements of Austrian Universities", paper presented at the IFSAM (International Federation of Scholarly Associations of Management), VIIlth World Congress September 28-30, 2006, Berlin, Germany. 
ARAUJO, A (2000): "Gestión del Conocimiento, Universidad y Empresa", Paper presented at Jornadas Universitarias sobre la gestión del conocimiento en empresas y organizaciones, Centre for University Knowledge Management, Bilbao, pp. 13-15.

ARROW, K.J. (1962): "The Economic Implication of Learning by Doing", Review of Economic Studies, $n^{\circ} 29$, pp. 155-173, June.

AUGIER, M. and D. J. TEECE (2005): "An economic perspective on Intellectual Capital", in Marr, B. (Ed.), pp. 3-27.

Austrian Research Centers (1999): "Intellectual Capital Report 1999", Austrian Research Centers, Seibersdorf.

Austrian Research Centers (2006): "Intellectual Capital Report 2005", Austrian Research Centers, Seibersdorf, Taken from: www.arc.ac.at.

BECKER, G.S. (1975): Human Capital, 2nd Edition, Chicago University Press, Chicago.

BOSSI, A. (2003): "La medición del Capital Intelectual en el Sector Público", Doctoral Dissertation. University of Zaragoza, Summary in: Revista Española de Financiación y Contabilidad, vol. XXXII, $\mathrm{n}^{\circ} 118$, pp. 921-925.

BOSSI, A.; FUENTES, Y. \& SERRANO, C (2005): "Reflexiones en torno a la aplicación del capital intelectual en el sector público", Revista Española de Financiación y Contabilidad, vol. XXXIV, n 124, pp. 211-245.

BROOKING, A. (1996): "Intellectual Capital: Core Asset for Third Millennium Enterprise", International Thomson Business Press, London.

CAÑIBANO, L.; GARCÍA-AYUSO, M. y SÁNCHEZ, M.P. (2000): "Accounting for Intangibles: A Literature Review”, Journal of Accounting Literature, vol. 19, pp. 102-130.

CAÑIBANO, L. and SÁNCHEZ, M.P. (2004): "Measurement, management and reporting on intangibles. State of the art", Cañibano, L. Sanchez, M.P. (Eds.), Readings on Intangibles and Intellectual Capital, AECA, pp. 81-113.

Center for Molecular Medicine (2005): Intellectual Capital Report 2004, Stockholm Offset, Norway.

Congreso de los Diputados (2007): Informe para potenciar y promover la responsabilidad social de las empresas, Ministerio de Trabajo y Asuntos Sociales, Madrid.

Comunidad de Madrid (2002): "Capital Intelectual y Producción Científica", Dirección General de Investigación, Consejería de Educación, Comunidad de Madrid, Madrid, Spain.

DENINSON, E. F. (1962): The Sources of Economic Growth in the United States and the Alternatives Before Us, Committee for Economic Development, New York.

ETZKOWITZ, H. \& LEYDESDORFF, L. (1996): "Emergence of a Triple Helix of University Industry Government Relations", Science and Public Policy, n² 23, pp. 279-286.

ETZKOWITZ, H. \& LEYDESDORFF, L. (2001): The dynamics of innovation: From National Systems and "Mode 2" to a Triple Helix of university-industry-government relations", $R e-$ search Policy, $n^{\circ}$ 29(2), pp. 109-123, http://users.fmg.uva.nl/lleydesdorff/th2/index.htm.

EUROPEAN COMMISSION (2000): Innovation Policy in a Knowledge-Based Economy, A Merit Study Commissioned by the European Commission Enterprise Directorate General, EUR 17023, http://www.cordis.lu/innovation-smes/src/studies.html.

EUROPEAN COMMISSION (2003): "The role of the Universities in the Europe of Knowledge" 05/02/2003, COM, Brussels, pp. 58 Final.

EUROPEAN COMMISSION (2005b): "Mobilising the brainpower of Europe: enabling universities to make their full contribution to the Lisbon Strategy", 20/04/2005, COM, Brussels, pp. 152 Final.

EUROPEAN COMMISSION (2006a): "RICARDIS (Reporting Intellectual Capital to augment research, development and innovation in SMEs)".

EUROPEAN COMMISSION (2006b): "Implementing the partnership for growth and jobs: making Europe a pole of excellence on corporate social responsibility".

EUROPEAN NETWORK FOR QUALITY ASSURANCE IN HIGHER EDUCATION (2003): "Quality Procedures in European Higher Education", ENQA Occasional Papers, 5, Multiprint, Helsinki, Finland. 
EUA (2005): Glasgow declaration: Strong Universities for a strong Europe, European University Association: www.eua.be.

EUA (2007): "Lisbon declaration: Europe's Universities beyond 2010: Diversity with a common purpose", European University Association: www.eua.be.

EXPANSIÓN (2008): "ESADE y Stanford se unen para formar líderes responsables", p. 15, 31 de marzo.

FORAY, D. (2004): The Economics of Knowledge, MIT, Cambridge, Massachusetts.

FREEMAN, C. (1982): The Economics of Industrial Innovation, 2nd Edition, Pinter Publishers, London.

GIBBONS, M. (1998): "Higher Education relevance in the 21st century", Education World Bank, UNESCO World Conference on Higher Education, Paris, October, pp. 5-9.

GIBBONS, M. LIMONGES, C.; NOWOTNY, H.; SCHWARTZMAN, S.; SCOTT, P. \& TWO, M. (1994): The New production of Knowledge: the dynamics of Science and Research in Contemporary Societies, Sage Publications, London.

GLOBAL REPORTING INITIATIVE (2006): "G·Guidelines", www.globalreporting.org.

GOREY R.M. y DOVAT D.R. (1996): Managing on the Knowledge Era, New York.

ICAC (2002): "Normas para el reconocimiento, valoración e información de los aspectos medioambientales en las cuentas Anuales", Boletín ICAC, n 49, pp. 29-34.

INGENIO (Instituto de la Gestión de la Innovación y del Conocimiento) (2002): "Portal de Conocimiento del II Plan de la Calidad de las Universidades", in: http://www.ingenio.upv.es/4_1_1b.html.

INSTITUTE OF CHARTERED ACCOUNTANTS IN ENGLAND AND WALES (2005): Information for better markets. New reporting models for business.

JEFATURA DEL ESTADO (2007): Ley Orgánica 4/2007 de 12 de abril, de Universidades, BOE, 13 April.

KENDRICK, J.W. (1974): "The Accounting of Human Investment and Capital", Review of Income and Wealth, $\mathrm{n}^{\circ} 20$, December.

LAREDO, A. (2007): "Revisiting the Third Mission of Universities: Toward a Renewed Categorization of University Activities?”, Higher Education Policy, vol. 20, n 4, pp. 441-456.

LEITNER, K.H. (2002): "The Transparent Enterprise. The Value of Intangibles", Intellectual Capital reporting for Universitites: Conceptual background and application within the reorganization of Austrian universities, Paper presented to the International Conference, Autonomous University of Madrid, Madrid, pp. 25-26, November.

LEITNER, K-H (2005): "Managing and Reporting Intellectual Capital in Public Research Organisations and Universities: Background, Development and Experiences of Austrian Organisations", Paper submitted to the 1st Workshop on "Visualising, Measuring, and Managing Intangibles and Intellectual Capital", Ferrara, pp. 18-20, October.

LEITNER, K-H. \& WARDEN, C. (2003): "Managing and Reporting Knowledge-based Resources and Processes in Research Organisations: Specifics, Lessons Learned and Perspectives".

LEITNER, K-H.; SCHAFFHAUSER-LINZATTI, M.; STOWASSER, R. and WAGNER, K. (2005): "Data envelopment analysis as method for evaluating intellectual capital", Journal of Intellectual Capital, vol. 6, $\mathrm{n}^{\circ}$ 4, pp. 528-543.

LEV, B. (2001): Intangibles: Management, Measurement and Reporting, The Brookings Institution, Washington D.C.

LUNDVALL, B.A. (Editor) (1992): National Systems of Innovation, Pinter Publishers, London.

MARR, B (Ed) (2005): Perspectives on Intellectual Capital. Multidisciplinary insights into Management, Measurement and Reporting, Elsevier Inc., Amsterdam.

MARR, B. and G. ROOS (2005): "A strategy perspective on Intellectual Capital", in Marr, B. (Ed.), pp. 28-41. 
MERITUM (2002): Guidelines for Managing and Reporting on Intangibles (Intellectual Capital Statements), Cañibano, L.; Sánchez, P.; García-Ayuso, M.; Chaminade, C. (Eds.), Vodafone Foundation, Madrid.

Ministério da Ciência, Tecnologia e Ensino Superior (2007): Diário da República, Regime Jurídico das Instituições de Ensino Superior (RJIES), Lei n. ${ }^{\circ}$ 62/2007, de 10 de Setembro, $1 .^{a}$ série, $\mathrm{n}^{\circ} 174,10$ de Setembro.

MOLAS-GALLART, J. (2005): "Defining, measuring and funding the Third Mission: a debate on the future of the university", Coneixement i Societat, vol. 7, pp. 6-27, January-April.

MOURITSEN, J.; THORBJORNSEN, S.; BUKH, P.N. and JOHANSEN, M.R. (2005): "Intellectual capital and the discourses of love and entrepreneurship in New Public Management", Financial Accountability and Management, vol 21, n 3, pp. 279-290.

MOVERY, D.C. \& SAMPAT, B.N. (2004): "Universities in National Innovation Systems", Paper presented in Globelics Academy, 25 May - 04 June, Lisbon, 2004, Available: http://www.globelicsacademy.net/pdf/DavidMowery_1.pdf.

NELSON, R. (Ed) (1993): National innovation systems: a comparative study, Oxford University Press, New York.

NONAKA, I. and TAKEUCHI, H (1995): The Knowledge-Creating Company, Oxford University Press, Boston, Massachussets.

Norwegian Ministry of Education and Research (2004): The Norwegian Competence Report 2003, Norwegian Ministry of Education and Research, Norway.

NYEN, T.; HAGEN, A. and SKULE, S. (2004): "Lifelong learning in Norwegian working life. Results from The Learning Conditions Monitor 2003", Fafo, Norway.

Observatorio de la RSC (2007): "Informe sobre RSC en las memorias anuales 2006 de las empresas del IBEX 35", www.observatoriorsc.org.

OECD (1996): The Knowledge-Based Economy, OECD. OCDE/GD(96)102, Paris.

OECD (2005): Oslo Manual: Guidelines for Collecting and Interpreting Innovation, 3rd Edition, OECD Publications, Paris.

OECD (2006): "Intellectual assets and value creation: Implications for corporate reporting", http://www.oecd.org/daf/corporate-affairs/.

OEU (2006): Methodological Guide. Strategic management of University research activities, Observatory of European Universities, PRIME Network of Excellence, Lugano, November, It may be downloaded from: www.uam.es/mpaloma.sanchez.

SÁNCHEZ, M.P.; ELENA, S. and CASTRILLO, R. (2005): "Intellectual Capital within Universities", Challenges for the OEU Project: Some proposals, Paper presented at the Observatory of European Universities (OEU), Budapest, December, pp. 1-2.

SANCHEZ, M. P. and ELENA, S. (2006): "Intellectual Capital in Universities. Improving Transparency and Internal Management", Journal of Intellectual Capital, vol. 7, n 4. pp. 529-548.

SÁNCHEZ, MP.; CASTRILLO, R. y ELENA, S. (2006): "The Intellectual Capital Report for Universities", OEU. Methodological Guide. Strategic management of University research activities, pp. 223-250.

SÁNCHEZ, M.P. and BASILIO, O. (2008): "Intellectual Capital and Innovation. A literature review for policy purposes", Paper presented to the International Forum on Knowledge Asset Dynamics, Matera, Italy, pp. 26-27, June.

SÁNCHEZ, M.P.; ELENA, S. and CASTRILLO, R. (2008): "Discussing the dynamics in Intellectual Capital in Universities. A model for reporting”, Journal of Intellectual Capital, Forthcoming.

SCHULTZ, T.W. (1969): "Investment in Human Capital", in Phelps, E.S. (Ed.), The Goal of Economic Growth, Norton, New York.

SENIOR, N.W. (1836): "An outline of the Science of Political Economy", Logman, London. Taken from Marr, B. (2005) "The evolution and convergence of Intellectual Capital as a Theme". In Marr, B. (ed.), "Perspectives on Intellectual Capital. Multidisciplinary insight into management, measurement and reporting", Elsevier, Amsterdam, pp. 213-226. 
SOLOW, R. (1957): "Technical change and the Aggregate Production Function", Review of Economics and Statistics, $\mathrm{n}^{\circ} 39$, pp. 312-20.

THOMSEN, S. (2004): Corporate governance and corporate objectives, Business School, Copenhaguen.

WARDEN, C (2003): "Managing and Reporting Intellectual Capital: New Strategic Challenges for HEROs", in IP Helpdesk Bulletin, $n^{\circ} 8$, April-May 2003: http:// www.iprelpdesk.org/newsletter/8/pdf/EN/N08_EN.pdf.

WILLIAMS, O.F. (2004): "The UN global compact: the challenge and the promise", Business Ethics Quarterly, nº 14. 
